\title{
Health researchers highlighted in online project
}

$\mathrm{S}$ cientists may become household names, like rock stars and basketball players, if a new social media campaign succeeds at profiling and reinforcing the value of their work.

Research2Reality aims to stimulate public curiosity in scientific research and will ultimately feature 70 short videos. The first 26 launched online May 11. At least half of the videos feature health and health technology researchers; other scientific disciplines include research on sustainable energy and natural resources.

"I don't think that anyone else in the world is doing what we're doing with Research2Reality," says Molly Shoichet, a professor of biomedical engineering at the University of Toronto who is steering the project. It's a way to break scientific research into "bitesized pieces."

The $\$ 400000$ awareness campaign on Facebook, Twitter, and YouTube is funded by the Government of Ontario and six research-intensive Canadian universities.

Shoichet teamed up with Mike MacMillan of Lithium Studios Productions to translate complex scientific concepts into two-minute visual pieces. These are followed by a short article with links to videos and more detailed information on the research.

"What we're trying to do with Research2Reality is to engage the public that is so receptive to research ... and make [it] a little bit more real to them."

The public may not be aware of why it's important for government to fund basic innovative research, she adds." The project may also inspire children to pursue careers in research. "We want to engage their curiosity in what's going on in research labs today and connect that to what will become our future tomorrow."

A stem cell scientist at McMaster University in Hamilton, Ont., Dr. Shelia Singh, is one of the researchers profiled in the health section. She says "scientists

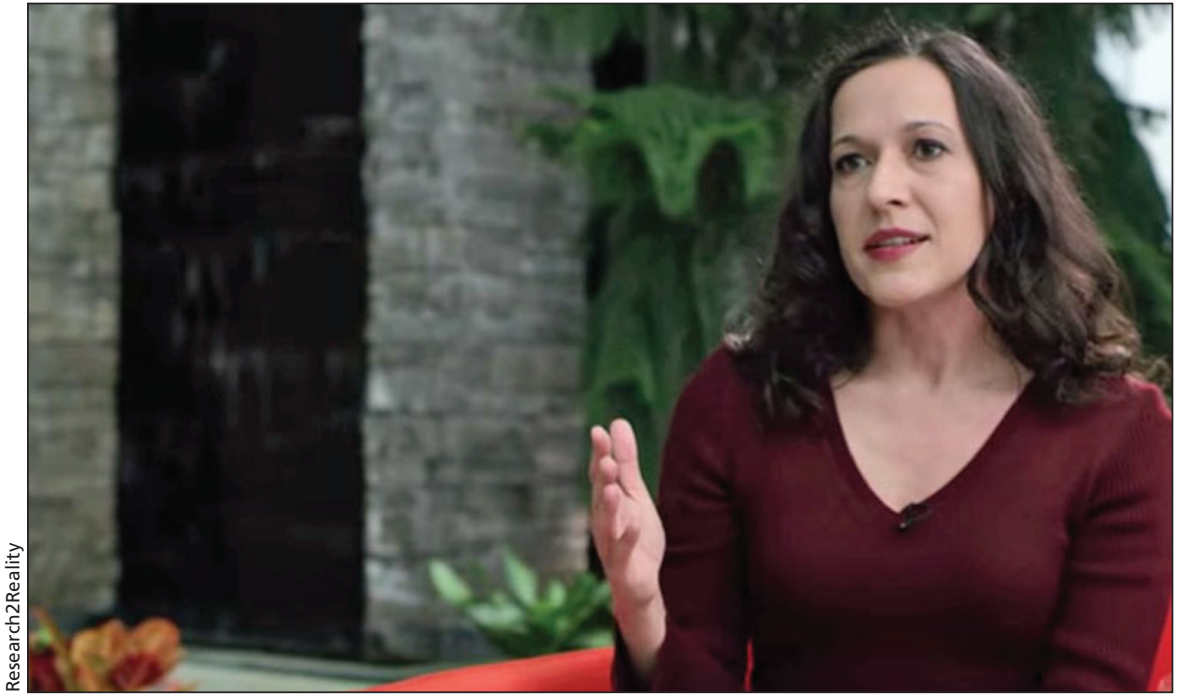

People could name a famous rock star or basketball player, says researcher Shelia Singh, but "who could name a famous scientist alive today?"

tend to be people who work quietly in their own environment," and although people could name a famous rock star or basketball player "who could name a famous scientist alive today?"

Singh is researching whether some cancer stem cells evade therapy, and if so how they can be targeted and removed. She estimates that she's received $\$ 4$ million over the past seven years from federal grants and donations through patient charities. But her work depends on the federal grants and accountability to the public is important to Singh. That's where Research2Reality comes in. "If it's more on their radar they could help give input on where research dollars should be spent."

Another Research2Reality feature profiles Patrick Gunning, a medicinal chemist at the University of Toronto who is studying treatments for cancer. "There are so many superstar scientists in Canada that most Canadians would never know about," says Gunning. "I think funding in Canada in general for sciences would be given higher priority if people knew the actual impact that our researchers have."

For the past eight years, Gunning and his students have been studying a treatment for pediatric brain cancer that is resistant to chemotherapy and radiation modalities, and showing "amazing results." This summer he's hoping to start human trials.

Gunning's research has garnered $\$ 13$ million in federal grants, as well as charitable and industry support. $\mathrm{He}$ says that funding for researchers is a lottery and it took him a while to get this level of funding.

Another scientist profiled, whose video hasn't been released yet, is Dr. Lori West, a medical researcher from the University of Alberta in Edmonton. She is the founding director of the Canadian National Transplant Research Program, a project to improve resources for transplant patients, and those waiting for organ and tissue transplants.

West hopes Research2Reality will help increase interest in rigorous science and debunk bad science. "The public has to become educated enough, or understand enough about complex scientific processes, to be able to look at those things to say this makes sense and this doesn't make sense."

The video series will continue to grow throughout the summer. - Shannon Lough, CMAJ

CMAJ 2015. DOI:10.1503/cmaj.109-5074 